\title{
LOCAL COMMUNITY VERSUS GLOBALIZATION TENDENCIES: CASE STUDY OF CZECH VILLAGES IN ROMANIAN BANAT REGION
}

\author{
MARKÉTA ŠANTRŮČKOVÁ ${ }^{1}$, MÁRIA PÁKOZDIOVÁ ${ }^{2}$, MONIKA HAMANOVÁ ${ }^{3}$ \\ ${ }^{1}$ Silva Tarouca Research Institute for Landscape and Ornamental Gardening, Publ. Res. \\ Inst., Květnové nám. 391, 25243 Prủhonice, Czech Republic; e-mail: santruckova@ \\ vukoz.cz \\ ${ }^{2}$ Faculty of Agronomy, Mendel University in Brno, Zemédělská 1, 61300 Brno, Czech \\ Republic; e-mail: 1Meryl@seznam.cz. \\ ${ }^{3}$ Faculty of Forestry and Wood Technology, Mendel University in Brno, Zemédělská 1, 613 \\ o0 Brno, Czech Republic; e-mail:mon.tvr@email.cz.
}

Received: $17^{\text {th }}$ February 2014, Accepted: $18^{\text {th }}$ June 2014

\begin{abstract}
The research question is the relationship between the local community and globalization tendencies and transformation or maintenance of local traditions. The research area is a specific locality of a Czech village in Romanian Banat. The local community has evolved in a relative isolation. Agriculture was the most important activity despite the fact that a mining factory was opened there. Agriculture was and in many features still is traditional, self-supplying, and hard-work. The life-style has always been environmentally friendly as it has been without modern technologies. Nevertheless, modernization exploded dramatically in these villages after 1989, when the communist policies collapsed along with Romania's isolation. People from the Czech Republic have rediscovered Romanian Banat and a rather busy (agro)tourism has developed there. The Czech Ministry of Foreign Affairs supports development projects for making living conditions in the village better. Simultaneously, strong migration from Banat to the Czech Republic has started. People find living conditions in the Czech Republic easier and leave hard work, poverty and unemployment. It brings huge land cover changes because people who remain cannot use all arable land, which is thus abandoned and left for the natural process. One of the distinct manifestations of globalization tendencies is the build-up of wind power plants.
\end{abstract}

Keywords: Romania; Banat; traditional society; modernisation; globalization

\section{INTRODUCTION}

This paper is concerned with the question of sustainable or unsustainable life in a chosen case study from a specific setting of a Czech village Sfanta Elena (Svatá Helena) in the Romanian Banat region. This very interesting area has come through a highly dynamic change during last 20 years, which has brought a revaluation of life attitudes and schemes of the local community having been formed for almost 200 years. Sfanta Elena is not the only Czech village in this region. It has been chosen for this study because of the best 
Šantrůčková, M., Pákozdiová, M., Hamanová, M.: Local community versus globalization tendencies: Case study of Czech villages in Romanian Banat region

accessibility, the biggest openness to its surroundings and its development trends having always been significantly reflected there. The paper is going to attempt to point out particular aspects of modernization and globalization tendencies, which are displayed in this specific setting and based on their analysis to answer the central question of the whole article, if the local community has shifted in the direction of sustainability or pro-environmental behaviour or not (Koroneos \& Rokos, 2012).

The aim of the paper was an attempt to answer such questions as following: Is the traditional way of life of the communities in the studied area sustainable or not? Are there any manifestations of modernization and globalization processes? If yes, how do the communities deal with these issues? Do they adjust to the new situation or do they hold back from it? If they hold back from it, which way do they so? What is the role of traditions in these issues?

The object of the study was one village from the Romanian Banat region, namely Sfanta Elena (Svatá Helena), where there is still a Czech enclave present. The village is rural settlements, what is crucial for maintenance of traditions, because the traditions are applied more distinctively in the countryside than in urban areas. The following criteria for the maintenance of traditions were chosen: religious traditions - the maintenance of customs connected to the Church and of religious rituals and cultural traditions (usually linked to the previous ones, or religious) (Pákozdiová, 2012).

\section{Basic characteristics of the studied area}

Sfanta Elena lies in a mountain terrain of the southern edge of the Carpathian Arch, in a karst environment of the Banat mountains at an altitude of about $400 \mathrm{~m}$ (above sea level), and thus it is the lowest situated Czech village in the Banat region. The local karst area has specific hydrological and pedological conditions that cause the lack of drinking water here. Rendzina is the predominant soil type. This area was colonized rather late. It is a border micro-region in the neighbourhood of the Danube river, which creates a natural border between Romania and Serbia (Fig. 1). The role of agriculture is still irreplaceable although it is in decline. In the cadastral territory of the village agricultural land (fields and grassland) predominates. A minor part is represented by forests. The landscape in Sfanta Elena surroundings is referred to as a cultural one, created by a human, with a high share of scattered vegetation, but with typical fields creating a colourful mosaic. The mosaic was developed from a hard work of local people, who once had to deforest large areas and have farmed on a small-scale on the deforested soil till now (Klvač, Buček \& Lacina, 2011; Langhammerová et al., 2009).

Sfanta Elena is not an independent administrative unit. It is under the administration of the nearby Romanian municipality Coronini. The number of permanent inhabitants of Sfanta Elena is 289 . This figure was made public on $2^{\text {nd }}$ February 2012 for the previous year 2011 on the website of the Romanian National Statistical Institute for Caraş-Severin County as an item about the number of inhabitants of the Coronini municipality who reported Czech nationality (Romanian Statistical Institute, 2012). On the website of the Coronini municipality 522 inhabitants for Sfanta Elena are presented, according to the census that took place in 2002 (Coronini Municipality, 2012). The area can be specified as peripheral. Sfanta Elena is a part of the Clisura Dunării micro-region, which is located on the left bank of the Danube river in the Locva Mountains (Munţii Locvei). A part of the microregion is situated in the Valea Mare Nature Reserve and the Porţile de Fier Natural Park (Klvač, Buček \& Lacina, 2011). The centre of the micro-region is a small town of Moldova Noua, situated near the Danube river. 
Fig. 1: General map of the studied area

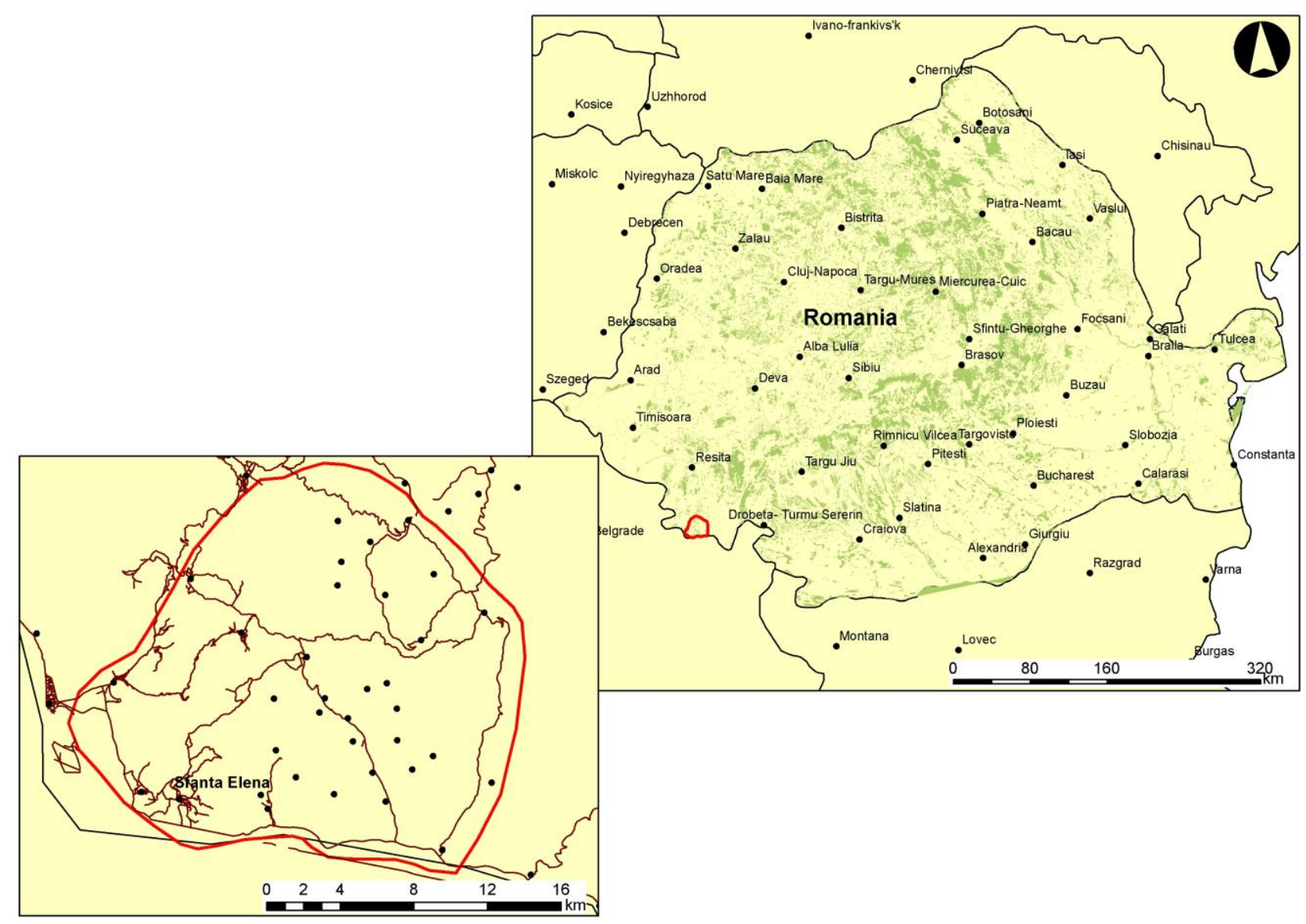


Šantrůčková, M., Pákozdiová, M., Hamanová, M.: Local community versus globalization tendencies: Case study of Czech villages in Romanian Banat region

The villages of the above mentioned microregion are located in a very hard accessible mountain terrain and their accessibility is even worsened by a bad quality of roads. The Clisura Dunării micro-region belongs to the Caraş-Severin County, which is classified as a less developed one within Romania.

The unemployment rate in this county is $8.6 \%$ (the data comes from 2010) (Romanian Statistical Institute, 2012), which represents the highest unemployment rate from all four counties creating the developing pole West, to which the Caraş-Severin county belongs. This developing pole is characterized by the second lowest GDP per capita in Romania and by a high unemployment rate, which is mainly caused by the decline of the extractive (coal and copper mining) and heavy industry. Other typical features are a lower level of urbanism and a total lower standard of living of the population. The pole is significant from the energetic point of view (water and coal energy). The area has a big potential of tourism development, which is seen in the combination of natural, balneological, religious and cultural attractive features; the potential is not sufficiently used yet (Bako \& Varvari, 2010).

In terms of religion, the village is separated from its surroundings; people in Sfanta Elena are of catholic and Baptist confession, while the Romanian surroundings is orthodox. The maintenance of traditions is very close linked to the religiosity, because many traditions are derived from the religious holidays. The Caraş-Severin County is multicultural and the Sfanta Elena village is one of the current six Czech villages of the Romanian Banat region. The others are: Gârnic (Gernik), Bigăr (Bígr), Ravensca (Rovensko), Eibenthal (Eibentál) and Şumiţa (Šumice) - the Romanian versions of the names of Czech villages in the Banat region are introduced first; the Czech versions are in the brackets.

\section{Historical development of the studied area}

The present settlement of the micro-region is quite young. The area was colonised as a part of a Habsburg monarchy Military border after the defeat of Turks and their displacement behind the Danube river in the $18^{\text {th }}$ century. The colonisation of the micro-region's centre, Moldova Noua, took place in the $18^{\text {th }}$ century by settlers from Styria and Tirol. The arrival of Czechs to the Banat region dates back to the first half of the $19^{\text {th }}$ century. Czech settlers colonised mainly higher woody areas (Hrůza, 1995; Urban, 2005). The aims of this colonisation were to deforest the area in order to cut wood and extend agricultural land, to establish a new settlement after the Turkish conquest and to strengthen the protection of borders (Iordache, 2007). Czechs came to Sfanta Elena and the nearby existing and later extinguished Elizabeth (Elisabethfeld) between 1820 and 1825. Sfanta Elena was founded by Evangelics and Elizabeth was settled by Catholics. The villages were a half hour walk away from each other $(1 \mathrm{~km})$. It is said that they got their names after two daughters of businessman Magyarli, who initiated the foundation of both villages. Elizabeth inhabitants moved to Sfanta Elena in by the year 1847. There are still fields and gardens in the area of former Elizabeth (Karas, 1938; Míčan, 1931). Between 1826 and 1830 the second Czech migration to the Banat Mountains proceeded and other Czech villages were established (Urban, 2005). Settlement of Czech villages in the Banat region stabilized in the middle of the $19^{\text {th }}$ century, when there were 7 Czech villages left. At this time a (catholic) school in Sfanta Elena was built, finished in 1850 and a chapel was built close to it. In 1879 a catholic church was built and in 1887 an evangelic one, later also a baptistic meeting-house.

The main occupation of the local population was agriculture. The Czechs and Germans with other colonists brought a new knowledge of agricultural methods to the Banat region and contributed to a modernization of the local agricultural production (Gräf \& Lumperdean, 2011). The most important crops were wheat, oat, rye, maize and potatoes. The plant production was complemented by keeping livestock, which was limited by the lack of 
pastures (Karas, 1938; Míčan, 1931). Except agricultural production, people seasonally cut woods or built roads. The inhabitants of Sfanta Elena were rather self-sufficient, including tools production for households and field works. Flour was milled, similar to other places in the Banat region, in simple water mills. Surplus products were sold at the nearby markets, especially in Moldova Noua. A typical dwelling was a house made of straw combined with wet clay crammed in between strong planks. This house consisted of two rooms, a food store and a kitchen. Behind the kitchen there were stables, a barn and an orchard (Karas, 1938; Jech et al., 1992).

The Banat region was a part of the 'Military border', which was created in 1716 and was directly managed by the Court Army Council in Vienna. In 1867 this area fell to the administration of the Hungarian Kingdom (Regnum Hungariae) and in 1873 the Military border was cancelled and the Banat region became a part of the Hungarian Kingdom (Míčan, 1931). After World War I this area was divided by the Treaty of Trianon in 1920 and Sfanta Elena with a big part of the Banat region became a part of Romania (Urban, 2005). At the end of the $19^{\text {th }}$ century and in the first half of the $20^{\text {th }}$ century, the population of Sfanta Elena started to increase by the natural growth increment on such a scale, that it turned to a relative overpopulation and the land did not manage to feed the whole population. That raised an emigration wave not only into the nearest towns, but also into neighbouring countries (especially to Bulgaria) and overseas. The emigrants sold or rented their estates only to the Czechs and that is the main reason why the village remained Czech (Urban, 2005). Its agricultural character was not changed even by an attempt of the entrepreneur Ježek from Bystré nad Metují to found a small textile manufacture in the village in 1927 (Urban, 2005). After World War II the emigration from Sfanta Elena culminated by the departure of a half of the population to Czechoslovakia. This re-emigration was organized by the Czechoslovakian government in order to colonize the depopulated border areas in Czechoslovakia (Hrůza, 1995). In the 1950s, an unsuccessful attempt of agricultural collectivization took place in Sfanta Elena. At the same time, ore mines were opened near Moldova Noua, where men from Sfanta Elena started to work at the turn of the 1970s and 1980s.

A big interest in the Czech countrymen came after the year 1989 (Kosinová, 2009) and tourism has gradually developed. The tourists are especially attracted by the traditional way of life of the local people and the natural environment in the neighbourhood of the Danube river. At the same time, another big wave of re-emigration of Banat Czechs to their old homeland started (Graf 1).

The negative outlooks of preservation and existence of the Czech ethnicity not only in Sfanta Elena but also in other Czech villages in the Banat region in Romania were strengthened by the next events. In 2005 the copper mines near Moldova Noua were closed with far-reaching consequences for the local population mainly in the form of losing their jobs as well as a significant part of their income. The environmental consequences after the end of the mining process (for example dustiness from the insufficiently secured dumps) are perceivable as well. 
Šantrůčková, M., Pákozdiová, M., Hamanová, M.: Local community versus globalization tendencies: Case study of Czech villages in Romanian Banat region

Graf 1: The development of the number of population in Sfanta Elena from 1830 till the present (Urban, 2005; Kosinová, 2009; Czoernig, 1857; Niederle, 1903; Auerhan, 1921; Svoboda, 1999)

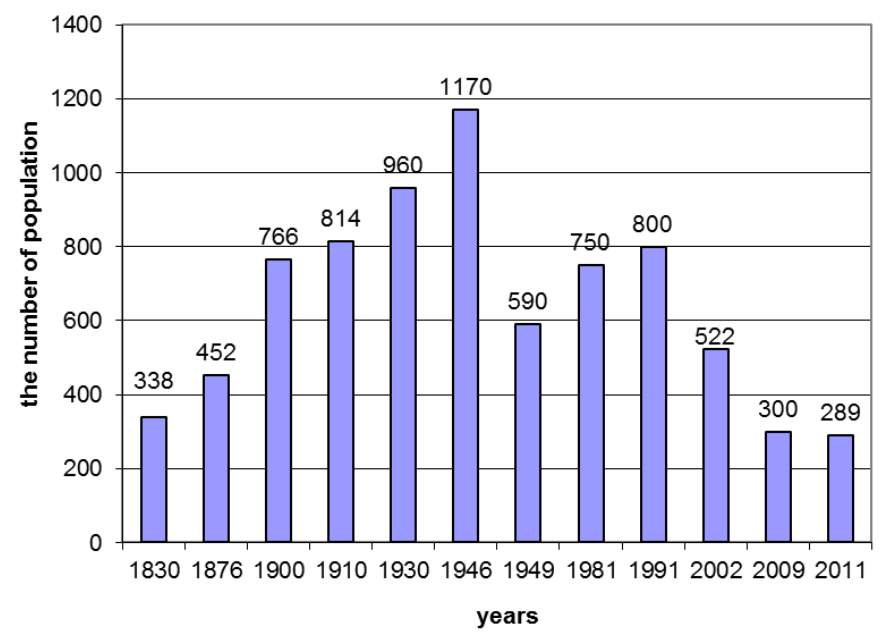

\section{METHODS}

An explorative empirical approach was adopted in order to identify local processes (Ortiz, Dienst \& Terrapon-Pfaff, 2012). Especially participant observation and prepared interviews with inhabitants of Sfanta Elena were used. We did not use questionnaires because they are inflexible. On the other hand, questions for interviews were carefully prepared in advance and interviews were monitored by the people who asked or by another researcher during the speech. Qualitative research methods were chosen for this study because we wanted to understand the issues mentioned above and generate data rich in detail. The methodology used in the study was ethnographical (according to e.g. Vanderstoep \& Johnston. 2009; Bickman \& Rog, 2009; Creswell, 2013). The research was based on the own field study in the village mentioned above. The following qualitative sociological research techniques were used: direct and participant observations. Direct observation is a tool that provides an unobtrusive documentation of physical aspects, behaviour and activities of people being observed (Tailor-Powell \& Steel, 1996). Participant observation or participant observational research (e.g. Erickson, 1985) enables researcher an insight into every day life activities of the studied people in the natural setting over an extended period of time. The researcher participates in those activities being a good listener interested in learning more about the others and thus creating a rapport within a community (Kawulich, 2005).

The research in the Czech villages of Romanian Banat region was based not only on observations but on semi-structured and non-structured interviews with the population of the studied area as well. A semi-structured (Given, 2008) or guided (Vanderstoep \& Johnston, 2009) or semi-standardized (Berg, 2001) interview is a compromise between an informal and structured interview and it combines the advantages of both the techniques (Vanderstoep \& Johnston, 2009). A non-structured (Rizk, 2003) or unstructured (McElwee, 2008; Given, 2008; Bernard, 1995) or unstandardized (Berg, 2001) or depth (Bloor \& Wood, 2006) or in-depth (Darlington \& Scott, 2002) or informal (Bickman \& Rog, 2009; Vanderstoep \& 
Johnston, 2009) interview is a sociological research technique that provides understanding of people from their own perspective. Using this type of interview any uncertainties of both sides, of the interviewer like of the interviewee can be immediately clarified (Darlington \& Scott, 2002).

Sometimes, particularly for affairs happened in the past, interviewing is the only method how to gain valuable information for the research. Interviewing can thus check the correctness of previous observations and complete them (Maxwell, 1996; Darlington \& Scott, 2002). A big advantage of an informal interview is a reduction of bias by collecting data in the research process. Plus unexpected discoveries are likely to be found in comparison with a preplanned structured interview (Vanderstoep \& Johnston, 2009). To the advantages of informal interviewing belongs a healthy rapport that can be established and maintained between the researcher and the community quite easily compared to other qualitative research techniques (Bickman \& Rog, 2009; Bloor \& Wood, 2006). Unfortunately, claimed by many authors (e.g. Vanderstoep \& Johnston, 2009; Fox, 2009; Patton, 2002; DeWalt \& DeWalt, 2002), this kind of interviews is mostly not comparable and the data gathered this way may not be generalisable. However, Bickman \& Rog (2009) write about comparison of people's perceptions and identifying shared values in the community by using informal interviews. An additional disadvantage is seen in quite a long duration by using this sociological research technique (Vanderstoep \& Johnston, 2009; Patton, 2002; Fox, 2009).

The field study was conducted within the following time frame 28. 4. - 1. 5. 2011, 31. 8. 3. 9. 2011 and 16. 9. - 22. 9. 2012, thus it has got a longitudinal character. Longitudinal qualitative research, particularly longitudinal qualitative interview (LQI), is used to understand development change, because it is conducted with the same people over a longer period of time (Hermanowicz, 2013). To investigate how people interpret and respond to any change (in this article: to any manifestations of modernization and globalization processes and shift in traditions) such a research is more than appropriate, it is even needed.

All interviews and fieldnotes were transcribed. Data gained were continuously supplemented due to email and Facebook conversation with the informants from the village. Email interview as an online qualitative research method can be used when it is not possible to use face-to-face-interview due to e.g. distance or other obstacles. Although the spontaneity of responding of both the interviewer and the interviewee is sacrificed and technical failure can sometimes occur as well, on the other hand email interviews reduce travel costs and time of transcription of obtained data (Given, 2008). Facebook as an online social network joins millions of users worldwide. As an online qualitative research method (as used in this research) it is economically and time effective as well as an email interview. Facebook, a dominant online social network in most countries, is available in over 70 languages and its user base is still growing (Samuels \& Zucco, 2012). According to observations many residents of the Czech villages in Banat region (those who have an internet access - in Sfanta Elena there is a computer with internet access almost in every household at the moment) use Facebook actively every day and some of them even more often than email conversation.

Chan (2009) indicates that observation may sometimes be the only assessment method possible in solving a research problem. Observation enables you to understand someone's perspective and meaning better than by listening to what people are saying about themselves during an interview. In addition, people are reluctant to reveal some information directly in interviews thus they remain undercover without using observation (Maxwell, 1996). In spite of that, using observation as a research method a researcher can face several disadvantages. One of disadvantages of direct observation seen by Chan (2009) is the fact, that this method is quite time-consuming. Furthermore, being watched can be intimidating and thus the presence of the observer can change peoples' behaviour. Unfortunately this affect can not be 
Šantrůčková, M., Pákozdiová, M., Hamanová, M.: Local community versus globalization tendencies: Case study of Czech villages in Romanian Banat region

fully removed in any case because every contact with the research object (observation, conversation, etc.) is actually an intervention (Breuer \& Roth, 2003). Another potential limitation of using observation, especially participant one is a researcher bias (Vanderstoep \& Johnston, 2009; Kawulich, 2005; Maxwell, 1996; Erickson, 1985). The researcher affects the observation by his/her theoretical approach, class, ethnicity, gender or other factors. $\mathrm{He} / \mathrm{she}$ should be aware of it not only by the observation itself but by the analysis and interpretation of data gathered as well (Kawulich, 2005). To reduce researcher's bias machine recording can be included into the research process (Erickson, 1985). Moreover, in participant observation accurate observation field notes (Maxwell, 1996) with the emphasis on researcher's non-biased theoretical perspective are essential (Kawulich, 2005). Another weakness of participant observation technique is that researcher can be easily excluded from the community from many reasons: a different language used within the community and by the researcher, a lack of trust from the members of the community towards an outsider, unwillingness to answer the researchers' questions etc. (Kawulich, 2005).

\section{RESULTS AND DISCUSSION}

\section{A present state of the tradition maintenance in Sfanta Elena}

Cultural traditions play an important role as stabilizers of the countryside. At the same time, the countryside is a space where the traditions have been more distinctively kept in comparison with urban areas. The question of the religiosity is crucial for the tradition maintenance, because many traditions are derived from religious holidays. In Sfanta Elena there are people of catholic and baptist confession, while the Romanian surrounding is orthodox (as already mentioned before). Many traditional customs and rituals have their origins in expressing a relation between a certain community and the nature. Pavlásek (2006) and similarly Hroch \& Mašek (2002) introduced 5 aspects which are responsible for the preservation of the Czech ethnicity (with its traditional way of life and customs) in the Romanian Banat region: natural conditions, unfamiliarity with the language of the majority, difference in religion, higher standard of living and strong relationships. These aspects are similar to the characteristics of peripheral regions. One of traditional manifestations of the culture of the local Czechs is the use of their language. Fluent Czech has been spoken in the Czech villages in the Romanian Banat region. The lives of Sfanta Elena's inhabitants still depend on the natural cycles much more than our lives. Thanks to the cultural closeness and worse accessibility of the terrain, the character of small-scale production (similar to the one in the Czech Republic before collectivization) has been preserved till nowadays (Klvač, Buček \& Lacina, 2011).

The local small-scale farming is closely linked to horse and cow setouts, which are an essential part of tillage by one earth-boarded plough and other agricultural and forest operations. Small tractors can be sometimes seen as well, but the use of agricultural mechanization is low especially because of the impassable terrain. At the harvesting time a reaping-hook and a scythe are still used, but a typical mowing-machine appears more often as well (Pavlásek, 2006). Fields are fertilized by organic fertilizers, while the use of mineral fertilizers is limited. Local people are still mostly self-sufficient in relation to ensuring basic food, but more and more foodstuff is bought. Traditions are an everyday part of life of the local people, whose mentality is still influenced by their belief to a large extent. Traditions refer to many aspects of everyday life (Langhammerová et al., 2009). As example we can take eating habits and food treatment. Typical are local specialities. The connection to a historical image of the Czech old homeland is still considerably strong. The image of the 
Czech Republic in the eyes of Sfanta Elena's inhabitants is considerably idealized, although the local people already get the newest information about the political situation and the standard of living in the country. The role of women in the local community is influenced by the religious tradition, so they are not completely equal. The girls get married relatively young and they generally do not attend a high school (Pavlásek, 2006). A conscious maintenance of specifics of the traditional Czech culture, especially the language, is reinforced by various means. Typical is, for example, acting superior above their Romanian neighbours, who are considered less intelligent and less hardworking (Pavlásek, 2006). Romanian influences entering the traditional culture of the Czech ethnicity are manifested not only in the local dishes, but also in taking-over some aspects of urban lifestyle; this is apparent for instance in modifications of the interior of their houses. No folk handicraft has been preserved in the village.

The life of the Czech ethnicity in Romania is considerably characterized by maintenance of traditions fixed especially to belief. Religious holidays with relevant customs are strictly kept. For example, Easter ("red holidays") as one of the important religious periods, is characterized by maintenance of rituals. Besides Easter, another religious event is the dedication day of a local church. The date of the dedication day in Sfanta Elena is the $28^{\text {th }}$ September on St. Wenceslaus' day. This day is also celebrated by re-emigrants living in the Czech Republic nowadays. The harvest festival has its constant date only in Sfanta Elena and it is the nearest Sunday to the St. Helena's Day, which is celebrated on the $18^{\text {th }}$ August. There are other still celebrated feast days: New Year's Day, Candlemas, Corpus Christi, All Soul's Day, St. Barbara's Day, St. Nicholas Day, Christmas (Langhammerová et al., 2009; Svoboda $\&$ Dokoupil 2005). The dances are connected with many religious holidays. Tourists brought the celebration of the New Year's Eve to the Banat region. A part of the tradition is the pilgrimage to Čiklava that proceeds twice a year (on the $15^{\text {th }}$ August - the Day of Assumption of the Virgin - and on the $8^{\text {th }}$ September - the Day of Birth of the Virgin). Czechs from all Banat villages take part in the mentioned pilgrimage (Pavlásek, 2006).

\section{Demonstrations of modernization and globalization in Sfanta Elena}

The expression of modernization is usually understood as gradual industrial and urbanization processes in a certain area. Before these processes occurred, this area was characterized predominantly by agricultural production or other branches of basic industries representing a part of traditional life of local communities. Modernization touched the traditional life of the village, every sphere of the rural people's lives. It did not have only positive effects (an increase in the standard of living), but negative ones as well. It touched for instance the way in which they make their living (the change from a total independence and self-support to the dependence on supplies of various products for the daily consumption), the rural architecture, the original social structure of the local community (it has changed to a typical individualism of anonymous urban environment; the patriarchal structure of family life with its given division of labour is disturbed), the relation to land. Another effect linked to modernization is a bigger blending of rural and urban way of life, because a part of the rural population accepted the urban models of life including use of their leisure time (Válka, 2011).

In Czech villages of the Romanian Banat region and especially in the most accessible one, Sfanta Elena, the modernization tendencies showed themselves distinctly after political changes in 1989, when the communist regime of Nicolae Ceaușescu fell. The consequence was the opening of Romania to the world, travel possibilities, foreign TV channels and new goods. That all brought fast changes of the traditional community which till that time had lived relatively closed, in traditional thought and production schemes. A further opening was 
Šantrůčková, M., Pákozdiová, M., Hamanová, M.: Local community versus globalization tendencies: Case study of Czech villages in Romanian Banat region

supported by the Romanian accession into EU on $1^{\text {st }}$ January 2007 together with Bulgaria. The Romanian government assumed that the country could become a member of the Schengen area in 2011, but it did not happen. Both Romania and Bulgaria have not gained unanimous support of member states in this area so far which is needed for the membership. Romania promotes "open-door" policy, which is a key factor for democratic reforms stimulation and economic development. After 1989 Czechs rediscovered their countrymen in Romania and a relatively busy tourism focused on Czech tourists in Czech villages has developed in the Banat region. Although it is ecotourism (Marzouki, Froger \& Ballet, 2012) and Czech tourists find authenticity and traditional livestyle there (Klvač, Hoření \& Krylová, 2009), Czechs have brought knowledge about modern technologies and lifestyle to these villages. By opening of the Romanian borders a significant migration wave from the villages started. The population is moving to the Czech Republic. That has stimulated the Czech government to finance or co-finance projects with the aim to maintain the Czech villages vital. The implementation of the projects is provided by the Czech NGO People in Need. In the first years the projects were focused on building of infrastructure (technical, transport) and ensuring education in the Czech language, followed by projects supporting job opportunities and living security, especially in the field of environmentally friendly tourism and small businesses. Environmentally friendly tourism has developed primarily in the Czech villages in the whole Danube gorge thanks to the Czech support. Approximately 6.000 Czech tourists per year come to the Banat region (Costachie et al., 2011).

In the 1990s Sfanta Elena was electrified and telephone service line was built in the village. The entry of the electricity into the village (and other Czech villages of the Romanian Banat region) caused a big technical revolution which meant a disruption of gradual development of the village that had been a neighbour's community till that moment (Svoboda \& Dokoupil, 2005). Nowadays, a TV set is a part of every household in Sfanta Elena and the majority of population owns a satellite. Watching several hundred soap operas became very popular as was confirmed by observations of spare time activities of the local people. Especially the young people got used to spending evenings watching Romanian TV programmes. Talks among neighbours, once so favourite, were reduced only for Sundays (Pavlásek, 2006; Pákozdiová, 2012; Costachie et al., 2011). Another, today already common, device is an automatic washing machine. Probably with the decline of the traditional hand washing and the coming of industrial washing powders, a local pollution may come anytime soon, especially surface and ground water pollution, because the water from the households flows to the landscape freely. Since the 1990s, the appearing cell phone has contributed to better communication with the world. The cell phone has gradually become a common part of households of $90 \%$ of population. In the last few years the internet was introduced in Sfanta Elena. It helps mainly as a means of fast and effective communication with relatives and friends in the Czech Republic. Today, the local people do not only have to remember and share the memories of the old Czech homeland as they did from generation to generation for a long time. Due to the internet connection and Skype programme they can create their own picture about the Czech Republic. Generally speaking, the local people welcome these technical news and they use them within their capabilities.

In a similar way, modernization is demonstrated also in other aspects of their everyday lives. For some years they have been harvesting using harvesters instead of mowing with a scythe and threshing. There are three machines available in Sfanta Elena. The mechanization contributed to the decrease in manual labour in the majority of fields (Pavlásek, 2006). People dress less and less in a traditional way and the dressing style has been adapting to urban environment. Mainly young people copy the fashion from the Czech 
Republic. The urban influences are visible also in architecture, especially in interior modifications (Pákozdiová, 2012).

Most of the roads in Czech villages of the Romanian Banat region are rather dusty or stony pathways than roads in the true sense of the word. Sfanta Elena is an exception. In 2005 a project of building an asphalt road leading from Coronini to Sfanta Elena was carried out. The project was financed by the Czech Republic and the European Union. The length of the road is over $5 \mathrm{~km}$. The asphalt road in Sfanta Elena leads to the crossroads in the middle of the village and the other roads in the village are non-asphalt ones. The state of the roads significantly contrasts with the new makes of cars which appeared in a great number after the opening of Romania to the world after 1989. The local people usually buy cars and register them in the Czech Republic. The interviews show that almost everyone in the village owns a car and sometimes even two (Pákozdiová, 2012).

A traditional and supported, although inconsistent, phenomenon is tourism. Sfanta Elena, being the most accessible from the Czech villages, was exposed to it as the first and has been exposed with the highest intensity. Czech tourists bring information about life in the Czech Republic into Sfanta Elena and they clearly demonstrate a life style that is in most cases in conflict with the traditional world of the local community. The developing tourism in the Czech villages is closely associated with the money it makes as it is one of the most important and sometimes the only income of the local people. The question of money is a sticky one in general, but particularly for the inhabitants of the studied village. According to the statements of the members of the local community, the cash flow especially from the tourism does not bring income only, but also social isolation of the rural people involved, who envy each other, as well as a bigger property and social stratification.

Not only society but also landscape is changing in the Romanian Banat region and especially around the Czech villages. It is natural because landscape is a mirror of the society. Former people had a lack of land and almost all land was used for agriculture. Fields, meadows and pastures were not only in the surroundings of Sfanta Elena but also several kilometres far from the village. Beech forests rested on hard accessible slopes and were used as a source of wood and for grazing livestock. The huge decrease in inhabitants caused that there is a relatively high amount of land now, first in Sfanta Elena's history. People do not need use all arable land within the cadastral borders and harder accessible or further fields, meadows and pastures are abandoned. Both intensity and extensity of land usage are deeply decreasing. Natural succession has started on the former arable lands. Areas of woods and shrubs increase, area of the arable land decreases.

One of the significant manifestations of globalization tendencies recently is the on-going construction of wind power plants in the territory of Sfanta Elena village at the turn of the years 2011/2012 (Fig. 2). These are 21 wind turbines with the capacity of 3 MW each and $140 \mathrm{~m}$ in height, conducted by Enel Green Power Romania Company, a subsidiary of the Italian Enel Group. Nine generators are located in the municipal pastures. The company did not succeed in buying these pieces of land thanks to of a Czech representative's opposition in the municipal council. The company is thus bound by a lease contract, from which an obligation to contribute to the municipal budget by a sum of 2.500 Euro for each of the 9 generators flows. The other generators stand on private pieces of land which were sold by the villagers for relatively low prices (starting at 400 Euro per hectare). There is a big risk that the constructions will negatively influence the developing potential of tourism and intact landscape of the Iron Gate Nature Park and the protected areas of NATURA 2000 scheme. Wind power plants round Sfanta Elena started not only environmental changes but they also influenced the landscape appearance and land cover. 
Šantrůčková, M., Pákozdiová, M., Hamanová, M.: Local community versus globalization tendencies: Case study of Czech villages in Romanian Banat region

\section{Fig. 2: Building plan of wind power plants in the surroundings of Sfanta Elena (People} in Need, 2012)

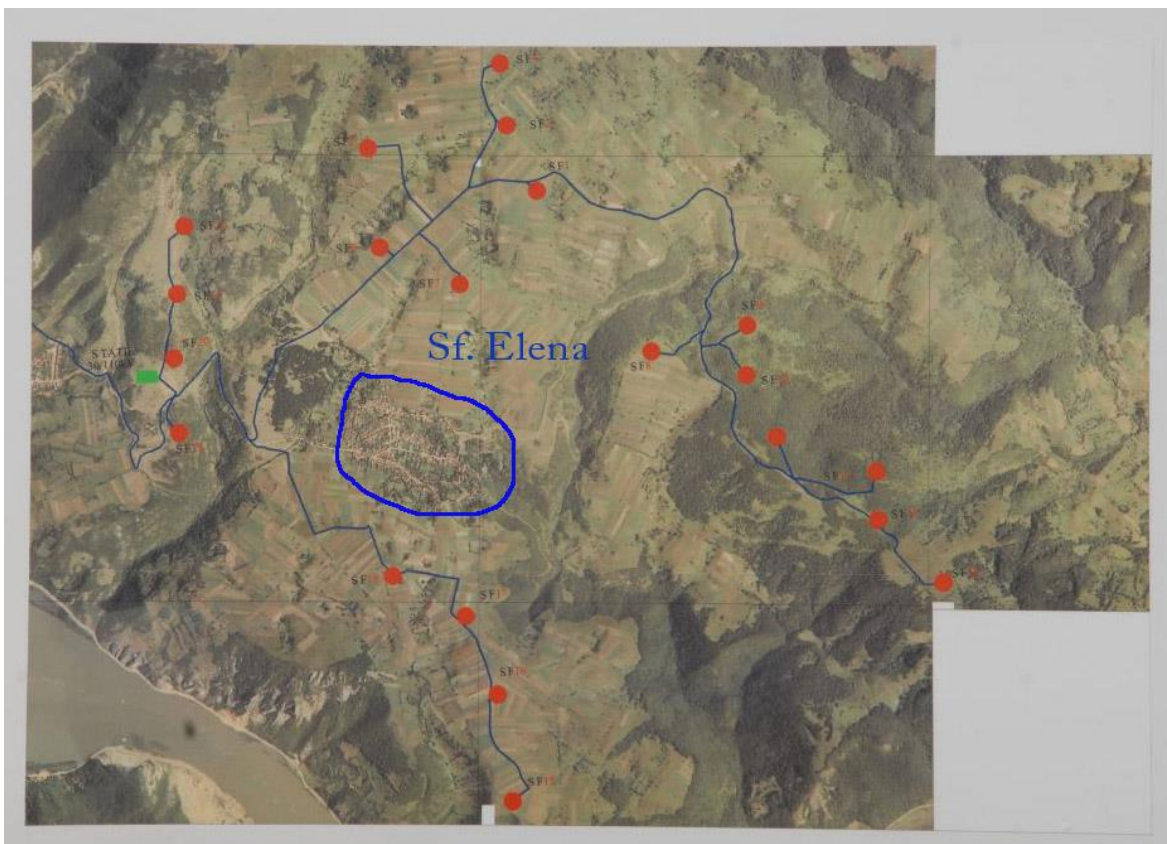

New wide roads and base circles of the poles were created instead of fields, meadows and pastures. The construction of wind turbines brings not only a significant change of the local landscape and destruction of the landscape character, but also an impact on the local community. This involves the erection of poles with the turbines, as well as the construction of consolidated wide roads for heavy mechanisation, which sharply contrast with the usual fieldpaths. Such roads represent a massive appropriation of agricultural land and have impacts on perception and "reading" of the landscape. On the other hand, the building of wind turbines in the surroundings of the village created a few job opportunities.

\section{Fig. 3: Wind power plants around Sfanta Elena}

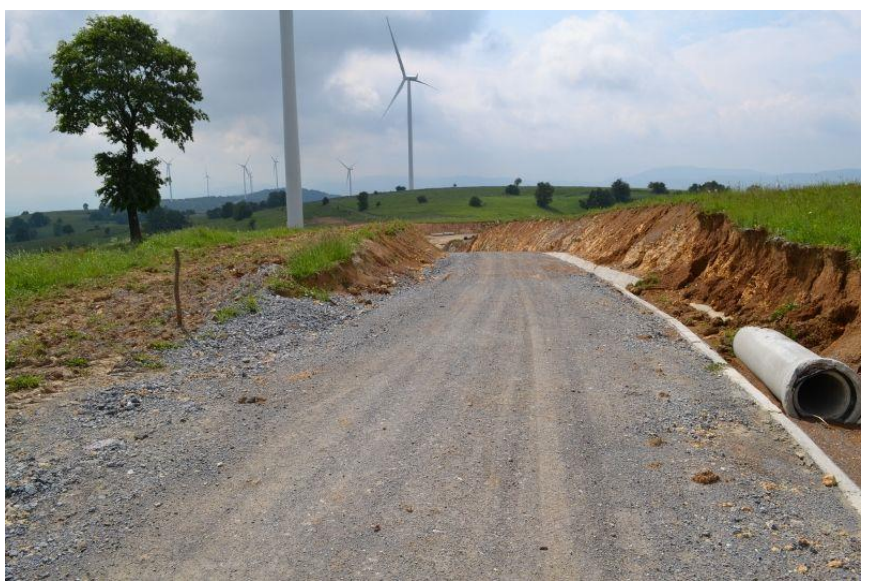


Concerning the fact that the building of wind power plants is finishing only in these days, it is not clear yet, what this massive change will bring next and if the decline of the tourism potential or directly the quality of life of the local population will come. Their attitude to the wind power plants is ambivalent, they perceive them through the perspective of Czech tourists and the biggest risk for them is a potential loss of their income from tourism (Pákozdiová, 2012).

Amongst other things, the construction of power plants certainly has a great influence on the environmental change. As demonstrated by the study of other areas where the construction is completed, the negative effects of power plants are many. In the investigated area, the biggest problem is a change in hydric conditions (Fig. 3). Already from a lay perspective, we can see that broad paths are ideal for a quick drainage of water and in areas such as karst they can have fatal consequences. Another problem is the loading and filled in sinkholes that have dramatically changed the landscape.

Wind turbines have inter alia a large impact on the fauna and not only avifauna but also bats. The problem was addressed several times by the conference Eurobats, where also studies concerning the number of deaths of bats who did not die as a result of a collision with a wind power plant, but only when passing close to it were presented (Rodrigues et al., 2006; Rodrigues et al., 2008). They suffer from the divers' disease when a propeller rotating near creates a vacuum which becomes mortal for the bats. $92 \%$ of them die from internal bleeding, which is caused by just this vacuum and not by a conflict with the propeller (Sw, 2008). The mortality study of bats was made by scientists from the Canadian University in Calgary. This phenomenon is officially called decompression sickness and is described well by divers - it comes when the organism cannot cope with the rapid emergence of the sharp drop in ambient pressure. A similar effect on avifauna and bats can therefore be expected around Sfanta Elena (Zagmajster, Jancar \& Mlakar, 2007). For example, in the wind park Tarifa in Spain 48 griffon vultures were killed in 1998. A wind farm in West Virginia in the U.S. killed approximately 4.000 bats -7 kinds of bats in the first year of operation (Buček, 2005; Kunz et al., 2007). The influence of wind power plants on nature and the landscape is known relatively little as well as the impact on the microclimate. Anyway, many previous studies have shown negative effects: on the fauna and flora, but also on the landscape. The impact, of course, will also hit tourism. At present, the impact appears positive so far when people go to Sfanta Elena to see what it looks like after the construction, but considering the examples from abroad, we can expect a decline in tourism. There are of course exceptions. In Germany when a wind park was built, the amount of cycle paths increased significantly as well as the tourist traffic. However, only future will show what impact this phenomenon will have on Sfanta Elena and its surroundings.

\section{CONCLUSIONS}

The traditional way of life of the rural community in Sfanta Elena has been preserved to a higher extent than it is usual in the Central European area these days. That is given mainly by a bigger isolation of the population from its surroundings (isolation given by natural environment and ethnical and religious difference). Nevertheless, it is affected by new influences such as an introduction of technical conveniences in the households and in the husbandry, tourism, more frequent contact with the surroundings, which is caused by the development of infrastructure and the youngest generation leaving for towns and cities in Romania or the Czech Republic. The young people try to change their previous conservative life in the countryside and get out of the dependence on parents and grandparents this way. 
Šantrůčková, M., Pákozdiová, M., Hamanová, M.: Local community versus globalization tendencies: Case study of Czech villages in Romanian Banat region

The parents and grandparents represent the "keepers" of the traditional way of life. The tradition and folk faith are rooted especially in the mentality of the middle age and the oldest generation (Pavlásek, 2006). The main reason for leaving is a lack of job opportunities in the area. In Sfanta Elena a general idea persists that there must be a better life in the Czech Republic, because there is enough work and money there. The village is at risk of decline in case all young people decide to move out and it is unsuccessful in maintaining the developing tourism potential that has been disturbed at least by the construction of wind power plants. Today, rather negative effects of this construction have been shown in the very surroundings of Sfanta Elena and a question of its usefulness in given conditions has to be raised. Was it only due to financial interests of the investor company which succeeded in gaining the building land from the local people at low prices or does Romania really want to join the idea of alternative energy sources and thus support the local community?

Coming back to the introductory question, we have to state that in the studied locality and community there is no shift to sustainable development or pro-environmental behaviour, although some of its aspects are present. In the case of the local community in Sfanta Elena, modernization broke into its life in a very significant way as well as a fascination with the technical conveniences and possibilities of modern life without people being aware of the risks linked to it. The self-sufficient and to the neighbouring landscape closely connected community has become increasingly dependent on its surrounding (urban) environment and there is a change of the traditional relations. Paradoxically, the most significant environmental action in the area has been the construction of the wind park that shall contribute to the decrease in the dependence on the overall consumption of fossil fuels in Romania. From the perspective of the local community, this project has some important negative drawbacks that consist in a significant disturbance to the landscape character and thus in a further weakening of the connection of the people to their landscape.

\section{ACKNOWLEDGMENTS}

The paper was elaborated within the project "Creation and Development of Multidisciplinary Team on the Basis of Landscape Ecology", number CZ.1.07/2.3.00/ 20.0004 of the Operational Programme "Education for Competitiveness".

\section{REFERENCES}

Auerhan, J. (1921). Čechoslováci v Jugoslavii, v Rumunsku, v Mad’arsku a v Bulharsku. Praha: Melantrich.

Bako, D. \& Varvari, S. (2010). Regional attractiveness in Romanian development regions. Revista Economica. 3, 59-66.

Berg, B.L. (2001). Qualitative research methods for the social sciences. Boston: Allyn and Bacon.

Bernard, H. (1995). Research methods in anthropology: qualitative and quantitative approaches. Lanham: AltaMira Press.

Bickman, L. \& Rog, D.J. (2009). The SAGE handbook of applied social research methods. Los Angeles: Sage Publications.

Bloor, M. \& Wood, F. (2006). Keywords in qualitative methods: a vocabulary of research concepts. Thousand Oaks, Calif: Sage Publications. 
Breuer, F. \& Roth, W.M. (2003). Subjectivity and Reflexivity in the Social Sciences: Epistemic Windows and Methodical Consequences. Forum Qualitative Sozialforschung. 4(2), Art. 25.

Buček, A. (2005). Diskuse. Veronica. 3, 29.

Chan, C. (2009). Assessment: Direct Observation. Hong Kong: University of Hong Kong.

Creswell, J.W. (2013). Research design: qualitative, quantitative, and mixed methods approaches. Thousand Oaks: Sage Publications.

Coronini (2012, February). Coronini municipality. Retrieved February 2, 2012, from http://primariacoronini.ro/

Costachie S. et al. (2011). Czech minority in Banat - Romania. A social geography survey. Geographica Pannonica. 15(1), 7-15.

Czoernig, K. (1857). Ethnographie der Oesterreichischen Monarchie. III. Band. Wien: Kaiserlich- Koeniglichen Hof- und Staatsdruckerei.

Darlington, Y. \& Scott, D. (2002). Qualitative research in practice: stories from the field. Allen: Crows Nest, N.S.W.

Dewalt, K.M. \& Dewalt, B.R. (2002). Participant observation: a guide for fieldworkers. Walnut Creek, CA: AltaMira Press.

Erickson, F. (1985). Qualitative Methods in Research on Teaching. Michigan: Institute for Research on Teaching, Michigan State University.

Fox, N. (2006). Using Interviews in a Research Project. Sheffield: The NIHR RDS for the East Midlands/Yorkshire \& the Humber.

Given, L.M., ed. (2008). The Sage encyclopedia of qualitative research methods. Los Angeles, Calif: Sage Publications.

Gräf, R. \& Lumperdean, I. (2011). Vorzeichen wirtschaftlichen Denkens. Die Erneuerung der siebenbürgischen und Banater Landwirtschaft (1711-1847). Transylvanian Review. 1, 111-128.

Hermanowicz, J.C. (2013). The Longitudinal Qualitative Interview. Qualitative Sociology. 36(2), 189-208.

Hroch, P. \& Mašek, V. (2002). Ve Valašsku zůstáváme. Čěstí krajané v Rumunsku. Praha: Gema Art.

Hrůza, F. (1995). Ze Svaté Heleny do Čech. Ostrava: A-Alef.

Iordache, C. (2007). Gârnic. The specifity of a Czech community in Romania. Analele Universitarii din Craiova. Serie Geografica, 10, 206-216.

Jech, J., Secká, M., Scheufler, V. et al. (1992). České vesnice v rumunském Banátě. In: S. Bouček (Ed.), Češi v cizině 5 (pp. 1-202). Praha: ÚEF ČSAV.

Karas, F. (1937). Československá větev zapomenutá nebem i zemí. Čechové v Rumunsku. Praha: Spolek Komenský v Praze.

Kawulich, B.B. (2005). Participant Observation as a Data Collection Method. Forum Qualitative Sozialforschung. 6(2), Art. 43.

Klvač, P., Buček, A. \& Lacina, J. (2011). Přiroda a krajina v okolí Svaté Heleny. Drnkovice: Občanské sdružení Drnka.

Klvač, P., Hoření, K. \& Krylová, R. (2009). "Hajdá do království sedláků" - o hledání autenticity v českých vesnicích v rumunském Banátu. In: P. Klvač (Ed.), Člověk, krajina, krajinný ráz (pp. 72-77). Brno: Masarykova Univerzita: Fakulta sociálních studií. 
Šantrůčková, M., Pákozdiová, M., Hamanová, M.: Local community versus globalization tendencies: Case study of Czech villages in Romanian Banat region

Koroneos, J.K. \& Rokos, D. (2012). Sustainable and Integrated Development. A Critical Analysis. Sustainability. 4, 141-153.

Kosinová, A. (2009). Česká menšina v rumunském a srbském Banátu: Komparativní analýza. Unpublished M.Sc. thesis, Univerzita Pardubice. Filozofická fakulta, Pardubice, Czech Republic.

Kunz, T.H. et al. (2007). Ecological impacts of wind energy development on bats: questions, research needs, and hypotheses. Front Ecol Environ. 5(6), 315-324.

Langhammerová, J., Kvaček, J., Mašek, P. et al. (2009). Český Banát. Život a tradice českých obyvatel rumunského Banátu, Praha: Národní muzeum.

Marzouki, M., Froger, G. and Ballet, J. (2012). Ecotourism versus Mass Tourism. A Comparison of Environmental Impacts Based on Ecological Footprint Analysis. Sustainability. 4, 123-140.

Maxwell, J.A. (1996). Qualitative research design: an interactive approach. Thousand Oaks, Calif.: Sage Publications.

McElwee, G. (2008). In search of Montsalvatch: Making sense of interviewing farmers. Tamara Journals. 2, 139-153.

Míčan, V. (1931). Za chlebem vezdejším. O československých osadnících v Rumunsku, Brno: Biblická Jednota v Brně.

Niederle, L. (1903). Národopisná mapa uherských Slováků na základě sčitání lidu z roku 1900, Praha: Národopisná společnost českoslovanská.

Ortiz, W., Dienst, C. \& Terrapon-Pfaff, J. (2012). Introducing Modern Energy Services into Developing Countries: The Role of Local Community Socio-Economic Structures. Sustainability. 4, 341-358.

Pákozdiová, M. (2012). Zachovávání tradic. Srovnávaci analýza Svaté Heleny a Hostětína. Unpublished M.Sc. thesis, Masarykova univerzita. Fakulta sociálních studií, Brno, Czech Republic.

Patton, M. Q. (2002). Qualitative Research and Evaluation Methods. Thousand Oaks, CA: Sage Publications.

Pavlásek, M. (2006). Úpadek tradice a změny v životě obyvatel Svaté Heleny. Unpublished B.Sc.thesis, Masarykova univerzita. Fakulta sociálních studií, Brno, Czech Republic.

People in Need (2012). Česká vesnice Svatá Helena je ohrožena výstavbou 21 větrných elektráren v bezprostředním okolí. Retrived December 7, 2012, from http://www.banat.cz

Rizk, N.J. (2003). Productive face-to-face interview. In: P. Constantinos and C. Zacharias (Eds.), Computer based learning in science (pp. 972-986). Nicosia: Department of Educational Sciences, University of Cyprus.

Rodrigues, L., Bach, L., Biraschi, L. et al. (2006). Wind Turbines and Bats: Guidelines for the planning process and impact assessments. Resolution 5.6. Strasbourg: EUROBATS.

Rodrigues, L., Bach, L., Dubourg-Savage, M.J. et al. (2008). Guidelines for consideration of bats in wind farm projects. EUROBATS Publication Series No. 3. Bonn: UNEP/ EUROBATS.

Romanian National Statistical Institute (2012). Caraş-Severin County. Retrieved February 2, 2012, from http://www.carasseverin.insse.ro

Samuels, D.J. \& Zucco C. (2013). Using Facebook as a Subject Recruitment Tool for Survey-Experimental Research. Retrieved February 17, 2014, from http://papers.ssrn.com/ sol3/papers.cfm?abstract_id=2101458\&download=yes

Svoboda, J. (1999). Česká menšina v Rumunsku. Praha: Sdružení Banát. 
Svoboda, J. \& Dokoupil, I. (2005). Banát. Turistický a vlastivědný průvodce českými vesnicemi v rumunském Banátě. Brno: Kudrna.

Sw (2008, August). Netopýři trpí nemocí potápěčů. Retrieved December 19, 2012, from http://horizontos.webnode.cz/news/netopyri-trpi-nemoci-potapecu/

Urban, R. (2005). Češi a Slováci v Rumunsku. Nadlak: Vydavatel'stvo Ivan Krasko.

Válka, M. (2011). Sociokulturní proměny vesnice. Moravský venkov na prahu třetího tisiciletí. Brno: Masarykova univerzita.

Vanderstoep, S.W. \& Johnston D.D. (2009). Research methods for everyday life: blending qualitative and quantitative approaches. San Francisco, CA: Jossey-Bass.

Zagmajster, M., Jancar, T. \& Mlakar, J. (2007). First records of dead bats (Chiroptera) from wind farms in Croatia. Nyctalus. 12, 234-237. 